\title{
Pediatric CNS-isolated hemophagocytic lymphohistiocytosis
}

Leslie A. Benson, MD, * Hojun Li, MD, PhD, * Lauren A. Henderson, MD, MMSc, * Isaac H. Solomon, MD, PhD, Ariane Soldatos, MD, MPH, Jennifer Murphy, MS, BSN, Bibiana Bielekova, MD, Alyssa L. Kennedy, MD, PhD, Michael J. Rivkin, MD, Kimberly J. Davies, MD, Amy P. Hsu, BA, Steven M. Holland, MD, William A. Gahl, MD, PhD, Robert P. Sundel, MD, Leslie E. Lehmann, MD, Michelle A. Lee, MD, PhD, Sanda Alexandrescu, MD,

Barbara A. Degar, MD, Christine N. Duncan, MD, $†$ and Mark P. Gorman, MD†

Neurol Neuroimmunol Neuroinflamm 2019;6:e560. doi:10.1212/NXI.0000000000000560

\section{Abstract}

\section{Objective}

To highlight a novel, treatable syndrome, we report 4 patients with CNS-isolated inflammation associated with familial hemophagocytic lymphohistiocytosis (FHL) gene mutations (CNSFHL).

\section{Methods}

Retrospective chart review.

\section{Results}

Patients with CNS-FHL are characterized by chronic inflammation restricted to the CNS that is not attributable to any previously described neuroinflammatory etiology and have germline mutations in known FHL-associated genes with no signs of systemic inflammation. Hematopoietic stem cell transplantation (HCT) can be well tolerated and effective in achieving or maintaining disease remission in patients with CNS-FHL.

\section{Conclusions}

Early and accurate diagnosis followed by treatment with HCT can reduce morbidity and mortality in CNS-FHL, a novel, treatable syndrome.

\section{Classification of evidence}

This study provides Class IV evidence that HCT is well tolerated and effective in treating CNSFHL.

\author{
Correspondence \\ Dr. Gorman \\ mark.gorman@ \\ childrens.harvard.edu \\ or Dr. Duncan \\ christine_duncan@dfci.harvard.edu
}

\section{$\rightarrow$ Class of Evidence}

MORE ONLINE

Criteria for rating therapeutic and diagnostic studies

NPub.org/coe

*These authors contributed equally to the manuscript.

tThese authors contributed equally to the manuscript and are co-corresponding authors.

From the Department of Neurology (L.A.B., M.J.R., M.P.G.), Boston Children's Hospital; Dana-Farber/Boston Children's Cancer and Blood Disorders Center (H.L., A.L.K., L.E.L., B.A.D., C.N.D.); Department of Rheumatology (L.A.H., R.P.S.), Boston Children's Hospital; Department of Pathology (I.H.S., S.A.), Boston Children's Hospital, Boston, MA; Undiagnosed Diseases Program (A.S., J.M., W.A.G.), National Human Genome Research Institute; Neuroimmunological Diseases Section (B.B.), Laboratory of Clinical Immunology and Microbiology, National Institute of Allergy and Infectious Diseases; Laboratory of Clinical Immunology and Microbiology (A.P.H., S.M.H.), National Institute of Allergy and Infectious Diseases, Bethesda, MD; and Division of Hematology, Oncology (M.L.A.), and Marrow and Blood Cell Transplantation, Children's Hospital at Montefiore, Bronx, NY.

Funding information and disclosures are provided at the end of the article. Full disclosure form information provided by the authors is available with the full text of this article at Neurology.org/NN. 


\section{Glossary}

ADEM = acute disseminated encephalomyelitis; CIS = clinically isolated syndrome; CLIPPERS = chronic lymphocytic inflammation with pontine perivascular enhancement responsive to steroids; FHL = familial hemophagocytic lymphohistiocytosis; GVHD = graft-versus-host disease; HCT = hematopoietic cell transplantation; HLH = hemophagocytic lymphohistiocytosis; IVIg = IV immunoglobulin; MDEM = multiphasic ADEM; NK = natural killer; WBC = white blood cell.

Despite advances in diagnostic capabilities in neuroimmunology, highlighted most dramatically by antineuronal antibody biomarkers, some patients continue to have idiopathic or poorly defined chronic and/or treatment-refractory neuroinflammatory disorders. Neuroinflammatory findings are present in more than half of the patients with hemophagocytic lymphohistiocytosis (HLH). ${ }^{1,2}$ However, systemic inflammation is a fundamental diagnostic component of HLH, which is traditionally characterized by cytokine storm, multiorgan dysfunction, and ultimately death if untreated. ${ }^{3} \mathrm{HLH}$ pathogenesis has been elucidated through the discovery of familial HLH (FHL)-associated genes, which encode proteins required for $\mathrm{CD}^{+}$lymphocyte and natural killer (NK) cell cytotoxicity. Deficiency in cytotoxic killing results in antigen persistence, leading to the hyperinflammatory state associated with FHL. ${ }^{4}$ The genes most commonly mutated in FHL are PRF1 (FHL2) and UNC13D (FHL3). ${ }^{5}$ Hematopoietic cell transplantation (HCT) is the only definitive cure for FHL. ${ }^{6,7}$

Although common at diagnosis of systemic HLH, CNS manifestations rarely precede systemic findings. ${ }^{1,2}$ Hemophagocytosis has been found in a brain biopsy of a patient not fulfilling the systemic HLH criteria. ${ }^{8}$ Patients with PRF1 mutations have been reported with isolated CNS inflammation for weeks to months before therapy initiation ${ }^{1,9-12} ; 2$ such patients underwent HCT. ${ }^{9,11}$ These reports raise, but do not answer, the question as to whether isolated chronic CNS inflammation can occur in the absence of systemic HLH findings.

Here, we describe 4 patients with progressive CNS-isolated inflammation and mutations in FHL-associated genes who never fulfilled the systemic diagnostic criteria for HLH, except for defective NK cell activity reflective of their underlying genetic mutations. The neuropathologic details of 3 of the patients ${ }^{13}$ and HCT outcome details of all 4 patients ${ }^{14}$ have been previously reported. HCT was well tolerated in these patients and resulted in arrest of disease progression, highlighted by the lack of development of morbidity in an asymptomatic patient with progressive radiologic neuroinflammatory findings.

\section{Case reports}

Baseline characteristics at diagnosis for all patients are described in the table.

\section{Patient 1}

The index case presented as a 5-year-old girl with headache, vomiting, mild ataxia, multifocal contrast-enhancing cerebral and cerebellar T2-hypertintense lesions (figure 1, figure 2), and CSF pleocytosis, meeting the diagnostic criteria for a demyelinating clinically isolated syndrome (CIS). ${ }^{16}$ Her symptoms and imaging findings responded to high-dose glucocorticoids (methylprednisolone $30 \mathrm{mg} / \mathrm{kg}$ IV for 5 days), but returned with steroid tapers despite monthly IV immunoglobulin (IVIg) ( $1 \mathrm{~g} / \mathrm{kg} /$ dose). Serial brain MRI identified enhancement patterns reminiscent of chronic lymphocytic inflammation with pontine perivascular enhancement responsive to steroids (CLIPPERS). ${ }^{17}$ Biopsy of a cerebellar lesion identified a mixed chronic inflammatory infiltrate with perivascular inflammation diffusely involving the gray and white matter and leptomeninges (figure 1). Induction treatment with glucocorticoids and cyclophosphamide followed by mycophenolate mofetil per small vessel CNS vasculitis protocol ${ }^{18}$ slowed, but did not halt, disease progression. She experienced progressive tremor, ataxia, dysarthria, dysconjugate gaze, and slowed speech and response time. Extensive evaluation including metagenomic next-generation sequencing of CSF and brain tissue was unrevealing for infection. Given her severe symptomatology, worsening course, and prominent $\mathrm{T}$ cells on repeat biopsy (left thalamic lesion, data not shown), natalizumab, which inhibits T-cell entry into the CNS, was given under a compassionate use investigational new drug protocol (IND 114796, $150 \mathrm{mg}$ for $4 \mathrm{mg} / \mathrm{kg}$ every $4-5$ weeks). While on natalizumab, her condition clinically and radiographically improved and then stabilized for 3 years before eventual clinical and radiographic progression. The patient was referred to the Undiagnosed Diseases Program at the $\mathrm{NIH},{ }^{19,20}$ but during the evaluation, she developed rotary nystagmus and worsened ataxia with loss of independent ambulation, partly responsive to high-dose methylprednisolone. Ultimately, CSF immunophenotyping and soluble biomarker analysis ${ }^{21}$ revealed activation of the innate immune system. $P R F 1$ gene sequencing identified biallelic previously reported, pathogenic mutations 5 years after initial presentation. CSF neopterin was significantly elevated (table). Throughout her course, patient 1 met no systemic HLH criteria except for decreased NK cell activity initially attributed to chronic immunosuppression. Following diagnosis, she received CNS-directed HLH therapy with intrathecal methotrexate and hydrocortisone and systemic dexamethasone with clinical improvement and normalization of the neopterin level before undergoing unrelated donor HCT at age 10 years.

\section{Patient 2}

A 6-year-old girl developed vomiting, headache, psychiatric symptoms, and cognitive decline over 3 months and then had focal status epilepticus prompting hospitalization. Additional symptoms noted during the hospitalization included left 
Table Characteristics of patients with CNS-FHL

\begin{tabular}{|c|c|c|c|c|c|}
\hline Patient & 1 & 2 (at diagnosis) & 3 & 4 & 2 (At relapse) \\
\hline Age at symptom onset (y) & 5 & 6 & 7 & NA & $\begin{array}{l}9 \text { (Symptom onset } 13 \mathrm{mo} \\
\text { posttransplant) }\end{array}$ \\
\hline Sex & $\mathrm{F}$ & $\mathrm{F}$ & $\mathrm{F}$ & $\mathrm{F}$ & \\
\hline Age at FHL diagnosis (y) & 10 & 8 & 13 & 11 & 9 \\
\hline \multicolumn{6}{|l|}{ Neurologic symptoms } \\
\hline Ataxia & $\mathrm{Y}$ & Y & $\mathrm{Y}$ & $\mathrm{N}$ & $\mathrm{N}$ \\
\hline Weakness & $\mathrm{Y}$ & Y & $\mathrm{Y}$ & $\mathrm{N}$ & $\mathrm{N}$ \\
\hline Seizure & $\mathrm{Y}$ & Y & $\mathrm{Y}$ & $\mathrm{N}$ & Y \\
\hline Headache & Y & Y & $\mathrm{N}$ & $\mathrm{N}$ & Y \\
\hline Vomiting & $\mathrm{Y}$ & $\mathrm{Y}$ & $\mathrm{N}$ & $\mathrm{N}$ & $\mathrm{N}$ \\
\hline Cognitive decline & $\mathrm{Y}$ & Y & $\mathrm{N}$ & $\mathrm{N}$ & $\mathrm{N}$ \\
\hline Other symptoms & $\begin{array}{l}\text { Esotropia, nystagmus, tremor, } \\
\text { and dysarthria }\end{array}$ & Dystonia and dysphagia & Diplopia and mood lability & $\mathrm{N}$ & Dystonia \\
\hline
\end{tabular}

\section{Immunotherapy before HLH}

\section{diagnosis}

\begin{tabular}{|c|c|c|c|c|c|}
\hline Oral steroids & $\mathrm{Y}$ & Y & Y & $\mathrm{N}$ & \\
\hline IV steroids & Y & Y & Y & $N$ & \\
\hline IVlg & Y & Y & Y & $\mathrm{N}$ & \\
\hline Cyclophosphamide & $\mathrm{Y}$ & Y & Y & $\mathrm{N}$ & \\
\hline Mycophenolate mofetil & Y & N & Y & $\mathrm{N}$ & \\
\hline Other immunotherapy & Natalizumab & Plasmapheresis & Rituximab and azathioprine & $\mathrm{N}$ & \\
\hline Mutation & $\begin{array}{l}\text { PRF1 c.452A }>\mathrm{T}(\mathrm{p} . \mathrm{H} 151 \mathrm{~L}) \text { and } \\
\text { c.666C }>\mathrm{A}(\mathrm{H} 222 \mathrm{Q})\end{array}$ & $\begin{array}{l}\text { PRF1 c. } 443 \mathrm{C}>\mathrm{G}(\mathrm{p} . \mathrm{A} 148 \mathrm{G}) \text { and } \\
\text { c.666C }>\mathrm{A}(\mathrm{H} 222 \mathrm{Q})\end{array}$ & $\begin{array}{l}\text { UNC13D c.2346_2349delGGAG } \\
\text { (p.R782fs), c.2588G>A (p.G863D) }\end{array}$ & $\begin{array}{l}\text { UNC13D c.2346_2349delGGAG } \\
\text { (p.R782fs), c.2588G>A (p.G863D) }\end{array}$ & $\begin{array}{l}\text { PRF1 c.666C }>\mathrm{A}(\mathrm{H} 222 \mathrm{Q}) \\
\text { heterozygous mutation in the first } \\
\text { HCT donor }\end{array}$ \\
\hline Systemic HLH evaluation ${ }^{a}$ & $\begin{array}{l}\text { No fever or splenomegaly, WBC } \\
13, \text { Hgb } 16.0 \text {, PIt } 359 \text {, ferritin } 36.5 \\
\text { fibrinogen } 407 \text {, and triglycerides } \\
56\end{array}$ & $\begin{array}{l}\text { No fever or splenomegaly, WBC } \\
22, \text { Hgb 13.6, Plt } 423 \text {, ferritin } 20.8 \text {, } \\
\text { fibrinogen } 443, \text { and triglycerides } \\
99\end{array}$ & $\begin{array}{l}\text { No fever or splenomegaly, WBC } \\
4.42, \text { Hgb } 14.2, \text { Plt } 346 \text {, ferritin } \\
71.9 \text {, fibrinogen } 365 \text {, and } \\
\text { triglycerides } 52\end{array}$ & $\begin{array}{l}\text { No fever or splenomegaly, WBC } \\
7.34, \text { Hgb 13.1, Plt 334, ferritin 31, } \\
\text { fibrinogen 242, and triglycerides } \\
124\end{array}$ & $\begin{array}{l}\text { No fever or splenomegaly, WBC } \\
6.42, \text { Hgb 13.4, Plt 215, ferritin } \\
281.7 \text {, fibrinogen 192, and } \\
\text { triglycerides } 62\end{array}$ \\
\hline $\begin{array}{l}\text { Soluble IL-2 receptor (unit/ } \\
\mathrm{mL} \text {, normal }<1,100 \text { ) }\end{array}$ & 265 & 209 & 710 & 647 & 519 \\
\hline
\end{tabular}


Table Characteristics of patients with CNS-FHL (continued)

\begin{tabular}{|c|c|c|c|c|c|}
\hline Patient & 1 & 2 (at diagnosis) & 3 & 4 & 2 (At relapse) \\
\hline $\begin{array}{l}\text { NK cell function (lytic units, } \\
\text { normal >2.6) }\end{array}$ & 1.7 & 0.0 & Lymphopenia too severe & 0.0 & 0.1 \\
\hline $\begin{array}{l}\text { NK cell perforin positivity } \\
\text { (normal } 73 \%-91 \%)\end{array}$ & $0 \%$ & $0 \%$ & Lymphopenia too severe & Not performed & $52 \%$ \\
\hline \multirow[t]{2}{*}{ NK cell CD107a } & Not performed & Expression 10\% (normal 11-35\%) & Lymphopenia too severe & Expression 3\% (normal 11-35\%) & Not performed \\
\hline & & $\begin{array}{l}\text { Mean fluorescence } 164 \text { (normal } \\
\text { 207-678 MCF) }\end{array}$ & & $\begin{array}{l}\text { Mean fluorescence } 72 \text { (normal } \\
\text { 207-678 MCF) }\end{array}$ & \\
\hline$\%$ ESR $(\mathrm{mm} / \mathrm{hr}) / \mathrm{CRP}(\mathrm{mg} / \mathrm{dL})$ & $7 / 0.17$ & $5 /<0.03$ & $12 / 0.5$ & $7 /<0.03$ & $8 / 0.11$ \\
\hline CSF WBC (per microliter) & 10 & 2 & 10 & 7 & 0 \\
\hline $\begin{array}{l}\text { CSF neopterin }(\mathrm{nmol} / \mathrm{L}, \\
\text { normal }<33)\end{array}$ & 48 & 150 & 24 & 22 & 14 \\
\hline \multicolumn{6}{|l|}{ Pre-HCT therapy } \\
\hline Enteral dexamethasone & Y & Y & Y & Y & Y \\
\hline $\begin{array}{l}\text { Intrathecal methotrexate/ } \\
\text { hydrocortisone }\end{array}$ & Y & Y & $\mathrm{N}$ & $\mathrm{N}$ & Y \\
\hline $\begin{array}{l}\text { Duration of follow-up post- } \\
\text { HCT (mo) }\end{array}$ & 36 & 13 mo to relapse & 28 & 25 & $11 \mathrm{mo}$ \\
\hline Post-HCT imaging & $\begin{array}{l}\text { No new lesions, no enhancement, } \\
\text { and diffuse encephalomalacia }\end{array}$ & $\begin{array}{l}\text { No new lesions, no enhancement, } \\
\text { and diffuse encephalomalacia } \\
\text { until } 13 \text { months posttransplant }\end{array}$ & $\begin{array}{l}\text { No new lesions and no } \\
\text { enhancement }\end{array}$ & $\begin{array}{l}\text { No new lesions and no } \\
\text { enhancement }\end{array}$ & $\begin{array}{l}\text { No new lesions, no enhancement, } \\
\text { and diffuse encephalomalacia }\end{array}$ \\
\hline $\begin{array}{l}\text { Pre- and post-HCT Modified } \\
\text { Rankin Scale }{ }^{15}\end{array}$ & 4 & 4 & 2 & 0 & 4 \\
\hline
\end{tabular}

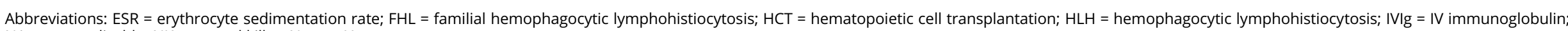
$\mathrm{NA}=$ not applicable; $\mathrm{NK}=$ natural killer; $\mathrm{N}=$ no; $\mathrm{Y}=$ yes.

${ }^{a}$ Fever $>38.0^{\circ} \mathrm{C}, \mathrm{WBC}=$ white blood cell count $\left(\times 10^{3}\right.$ per $\left.\mu \mathrm{L}\right), \mathrm{Hgb}=$ hemoglobin $(\mathrm{g} / \mathrm{dL})$, Plt = platelet count $\left(\times 10^{3}\right.$ per $\left.\mu \mathrm{L}\right)$, ferritin $(\mathrm{ng} / \mathrm{mL})$, fibrinogen $(\mathrm{mg} / \mathrm{dL})$, and triglycerides $(\mathrm{mg} / \mathrm{dL})$. 
Figure 1 Imaging and histopathologic characteristics of patients with CNS-FHL

Prediagnosis
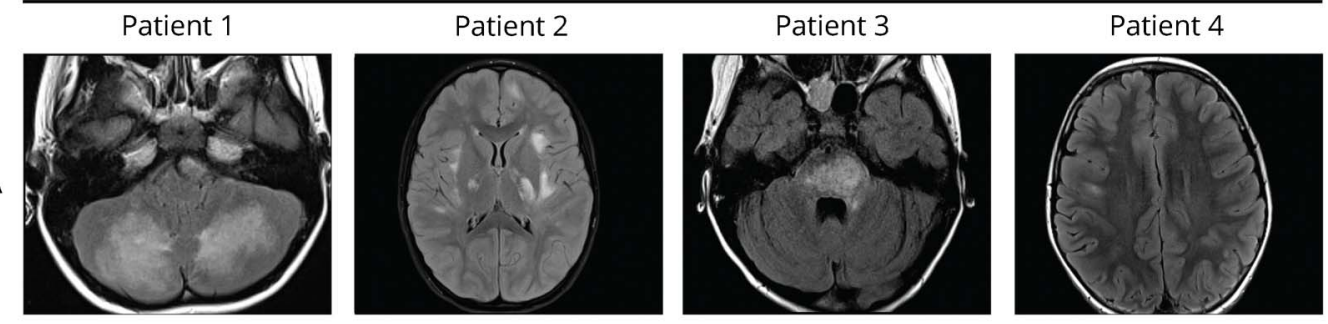

Patient 2 at relapse
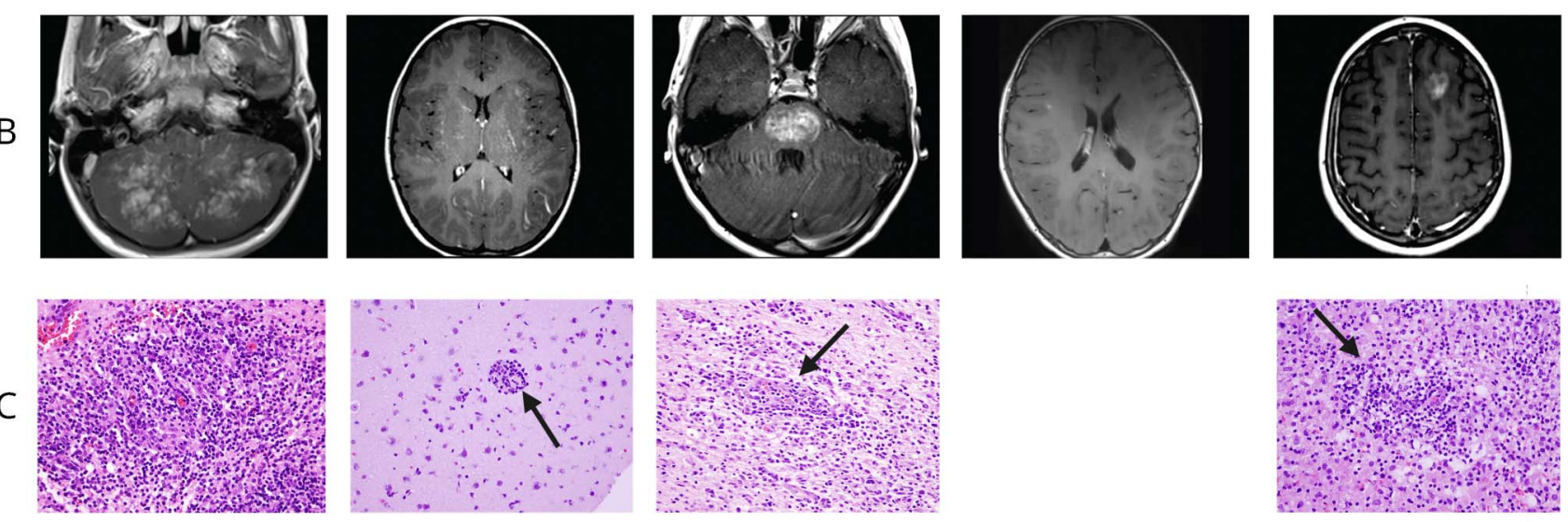

Patient 1 post-HCT

Patient 2 post-HCT \#1

Patient 3 post-HCT
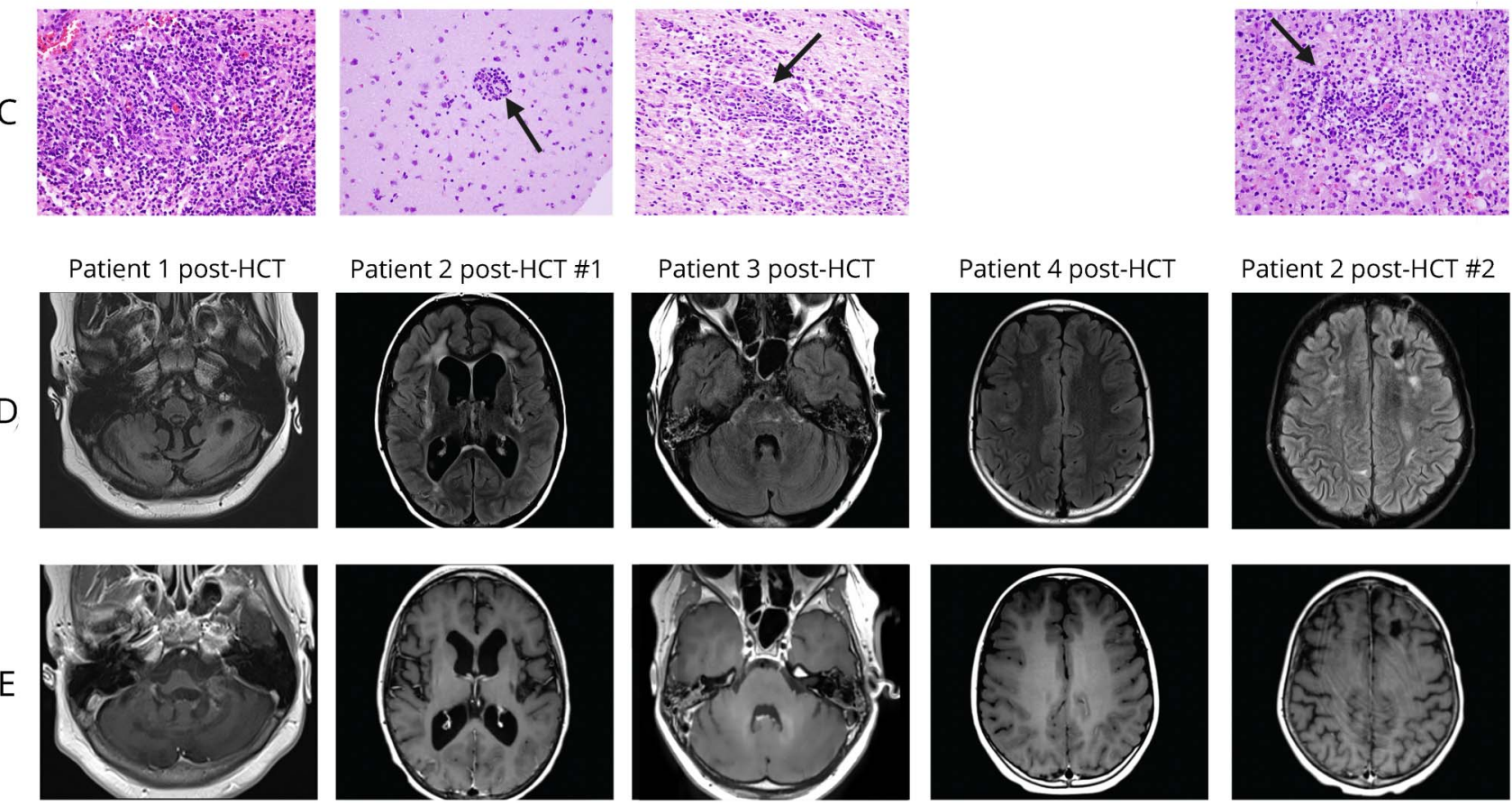

Patient 2 post-HCT \#2
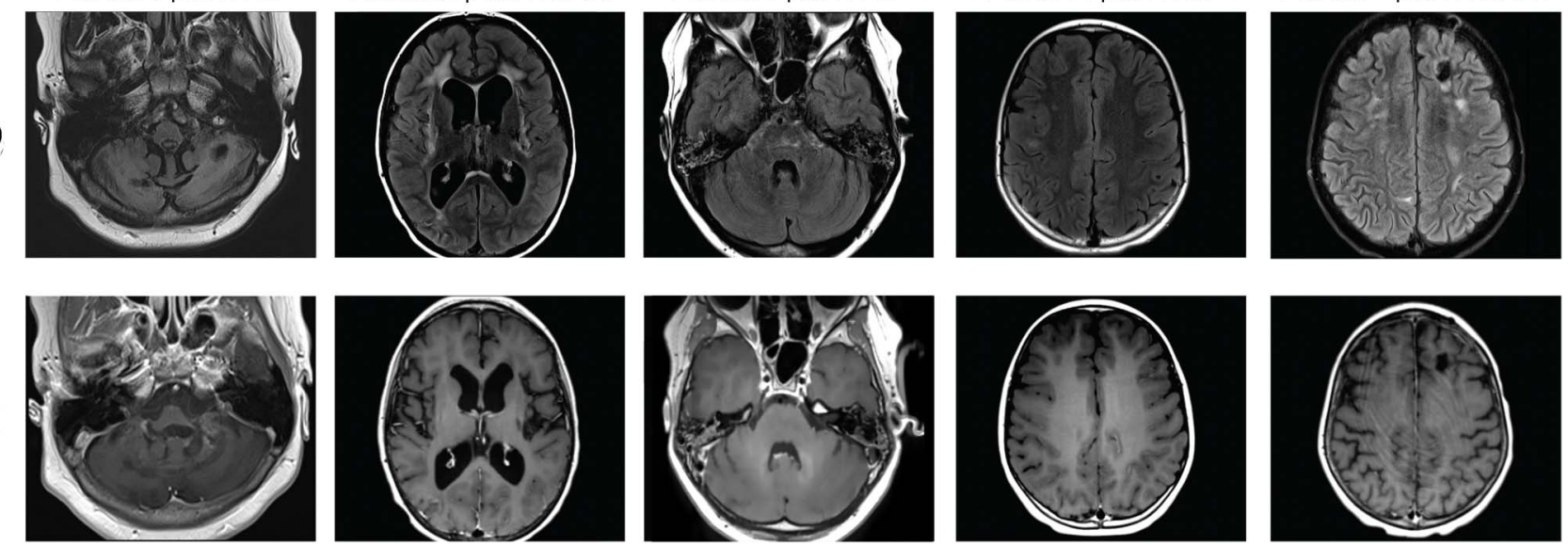

FLAIR (row A) and post-contrast T1 (row B) MRI findings for patients before initial diagnosis or at relapse. Note the varied lesion appearance with small multifocal, confluent, and tumefactive lesions. Punctate and curvilinear enhancement resembling CLIPPERS is common to 3 of the 4 patients early in disease. Patient 4 had multifocal small lesions with a single area of enhancement. Avid enhancement was a common feature of new or active lesions. Over time, lesions became confluent, and diffuse atrophy evolved in patients 1 and 2. Representative histopathology (row C) images from prediagnosis or relapse biopsies demonstrating a diffuse mixed chronic inflammatory infiltrate in patient 1, foci of perivascular lymphocytes (arrow) extending into the parenchyma for patient 2 prediagnosis, perivascular (arrow) and parenchymal mixed chronic inflammatory infiltrate with small vessel vasculitis in patient 3, and destructive perivascular (arrow) and parenchymal lymphohistiocytic infiltrate in patient 2 at relapse (magnification: $\times 40$ objective). Post-HCT FLAIR (row D) and post-contrast T1 (row E) MRI images demonstrate resolved enhancement and no development of new lesions for patients 1, 3, and 4 after HCT \#1 and for patient 2 after HCT \#2. CLIPPERS = chronic lymphocytic inflammation with pontine perivascular enhancement responsive to steroids; FLAIR = fluid-attenuated inversion recovery; $\mathrm{HCT}=$ hematopoietic cell transplantation.

hemiparesis and dystonia. Brain MRI identified contrastenhancing cerebral and cerebellar white matter T2 hyperintense lesions (figures 1 and 3). She met the criteria for and was diagnosed with acute disseminated encephalomyelitis $(\mathrm{ADEM})^{16}$ and received pulse methylprednisolone IV for 3 days and IVIg, followed by tapering daily oral prednisolone with gradual partial improvement. However, 4 months after the seizure, while off immunotherapy, she re-presented with headache, vomiting, lethargy, worsened motor and language function, and new MRI lesions prompting additional IV methylprednisolone and 5 sessions of plasmapheresis. The presentation now met the criteria for multiphasic ADEM (MDEM). She was then treated with 3 doses of monthly IV cyclophosphamide. Over the next 8 months, she had interspersed periods of improvement and worsening, including 2 episodes of status epilepticus. Treatments during this time 
Figure 2 Patient $1 \mathrm{MRI}$ evolution over time

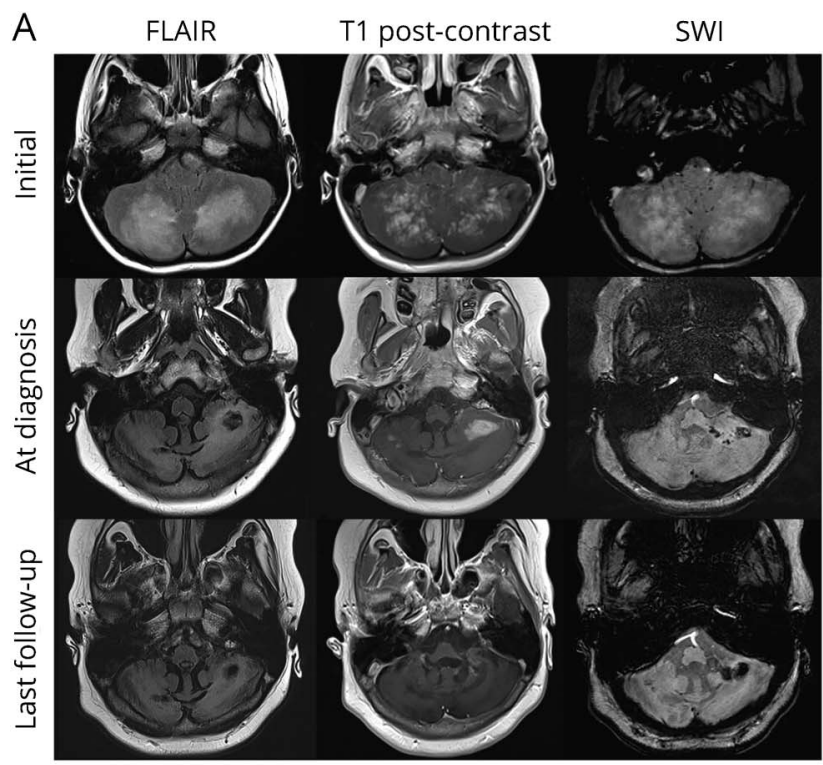

B

FLAIR

T1 post-contrast

SWI

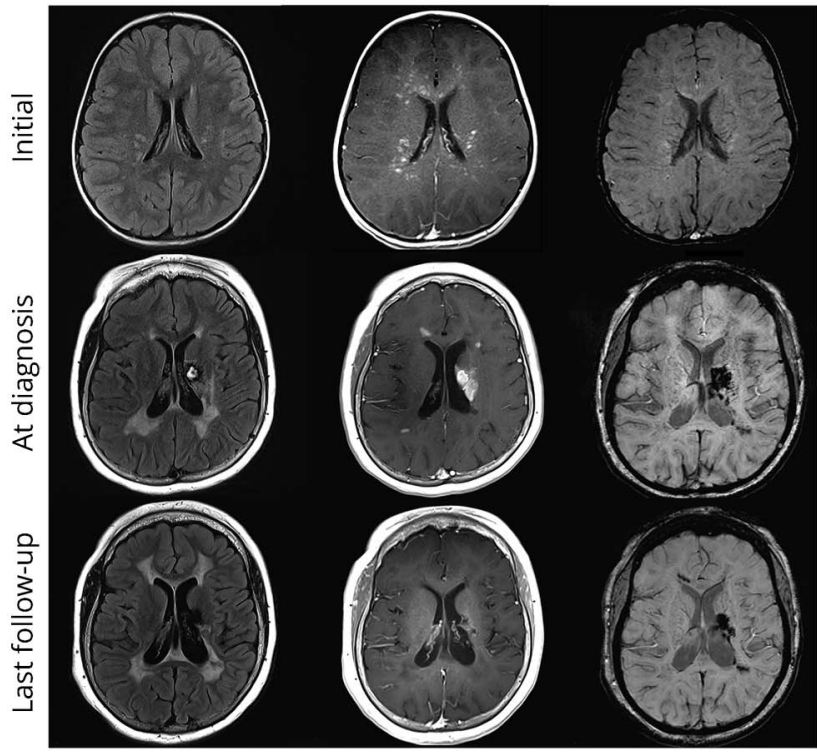

(A) Confluent cerebellar FLAIR lesions with punctate, folia, and curvilinear enhancement without SWI change evolved to cerebellar atrophy with confluent nodules of enhancement and associated accumulation of microhemorrhages. Pattern persists posttransplant but without enhancement. (B) Supratentorial multifocal asymmetric small well-circumscribed lesions all with avid enhancement without initial SWI change evolving to confluent FLAIR lesions with punctate and confluent areas of enhancement and SWI change over time leading up to transplant. Imaging remains stable posttransplant. FLAIR = fluid-attenuated inversion recovery; SWI = susceptibilityweighted imaging.

included IV and oral corticosteroids and IVIg. Serial brain MRI showed accumulation of multifocal T2 hyperintense lesions, becoming confluent in the bilateral periventricular white matter, as well as progressive supra- and infra-tentorial atrophy, necrosis, and scattered hemorrhages (figure 3). Nineteen months after her first symptoms, she developed dysphagia and worsened dystonia and was referred to Boston Children's Hospital. Biopsy of a frontal lobe lesion showed perivascular lymphocytic foci with parenchymal extension
Figure 3 Patient 2 MRI evolution over time before relapse

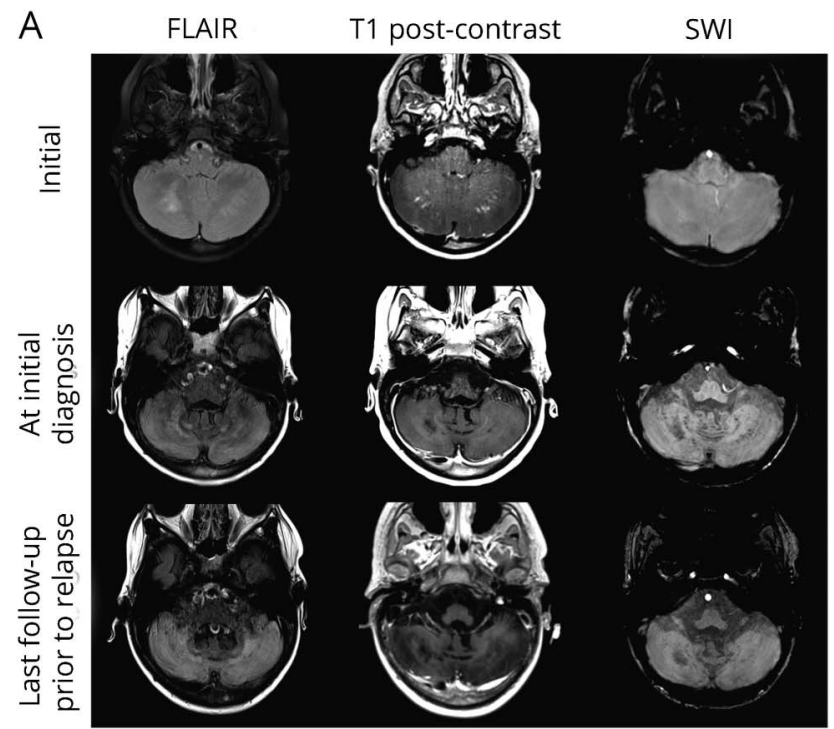

B

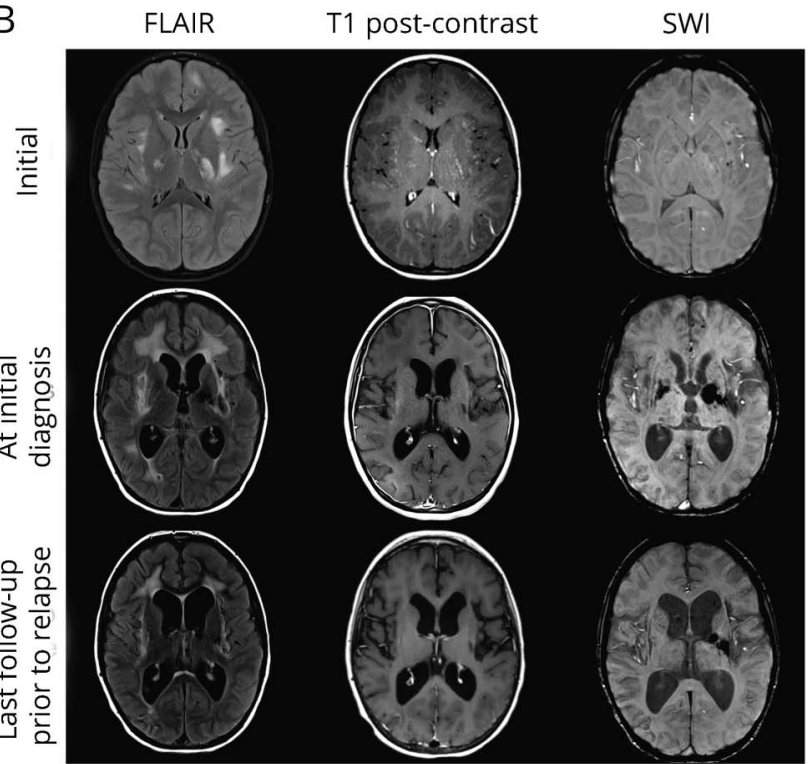

(A) Cerebellar FLAIR lesions with punctate and curvilinear enhancement without SWI change evolved to cerebellar atrophy with confluent nodules of enhancement and associated accumulation of microhemorrhages. Pattern persists posttransplant, but enhancement responded to treatment. (B) Supratentorial multifocal asymmetric lesions with white matter, cortical, deep gray, and insular predilection with initial punctate enhancement evolving to curvilinear cortical enhancement. No initial SWI change evolving to punctate and confluent areas of SWI change consistent with hemorrhage over time leading up to transplant. Posttransplant FLAIR lesions become smaller with further global brain atrophy. FLAIR = fluid-attenuated inversion recovery; SWI = susceptibility-weighted imaging.

(figure 1). CSF neopterin was elevated. Based on imaging similarities to patient 1 , reanalysis of previously performed whole-exome sequencing with attention to FHL genes identified biallelic PRF1 mutations (1 previously reported in FHL2, 1 novel). She met no systemic HLH criteria except for decreased NK cell activity. She received intrathecal methotrexate and hydrocortisone and systemic dexamethasone before undergoing HLA-matched sibling donor HCT at age 9 years. 


\section{Patients 3 and 4}

Patient 3 presented as a 7-year-old girl with diplopia, right hemiparesis, ataxia, CSF pleocytosis (white blood cell [WBC] count $10 / \mu \mathrm{L}$ with $85 \%$ lymphocytes), and multifocal brain lesions, including a large brainstem lesion (figure 1), leading to diagnosis of a demyelinating CIS. Symptoms and MRI findings transiently improved with methylprednisolone IV 30 $\mathrm{mg} / \mathrm{kg} / \mathrm{d}$ for 5 days, followed by prednisolone starting at 1 $\mathrm{mg} / \mathrm{kg} / \mathrm{d}$ and tapered over 3 months, but she developed seizures and new contrast-enhancing lesions similar to CLIPPERS (figures 1 and 4) 7 months after initial presentation. Biopsy of a frontal lobe lesion showed extensive

Figure 4 Patient 3 MRI evolution over time

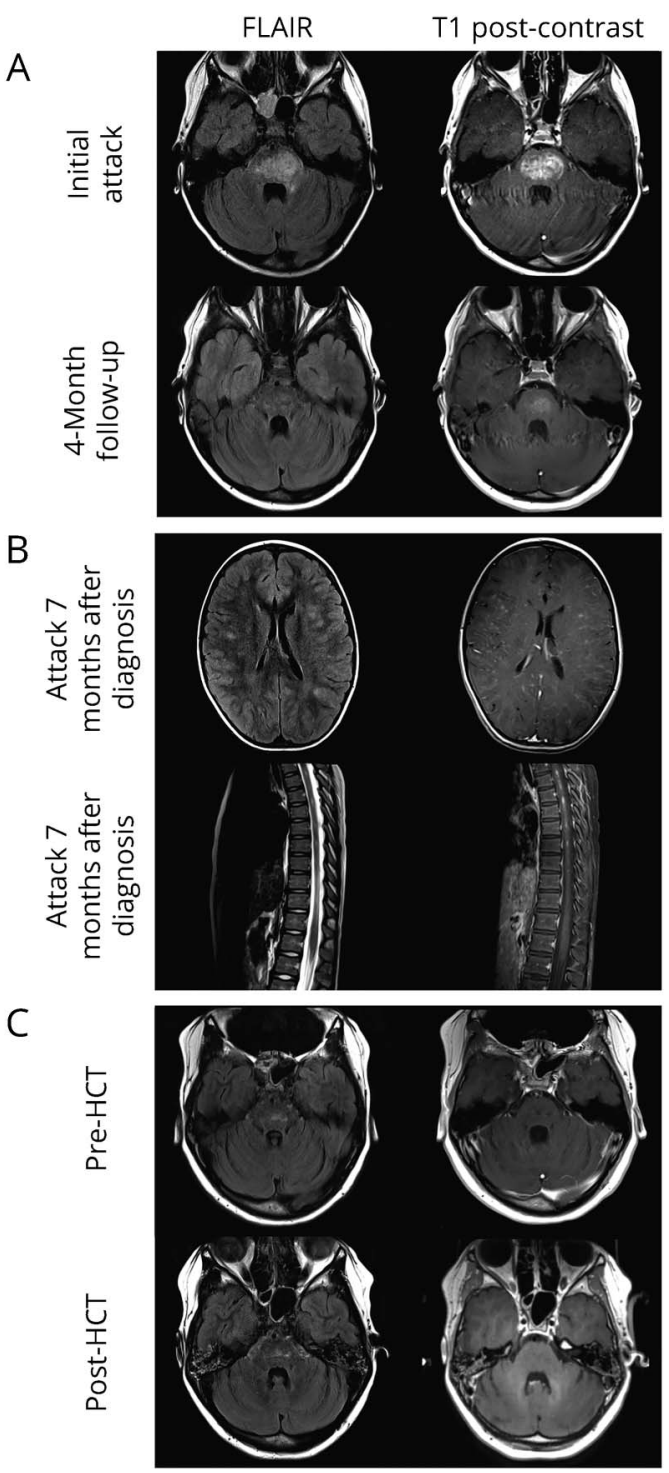

(A) Initial attack and follow-up FLAIR and T1 post-contrast images showing tumefactive brainstem lesions with heterogeneous enhancement pattern. Significant improvement with steroids at 4-month follow-up. (B) Attack 7 months from onset with multifocal FLAIR lesions throughout the brain and spinal cord with punctate, speckled enhancement throughout. (C) Pre- and post-HCT images of the cerebellar involvement with minimal atrophy over time in this patient despite 7 years of disease. FLAIR = fluid-attenuated inversion recovery; $\mathrm{HCT}=$ hematopoietic cell transplantation. vascular, perivascular, and parenchymal mixed inflammatory infiltrates with occasional small vessel vasculitis (figure 1). Despite treatment with a small vessel CNS vasculitis protocol, ${ }^{18}$ symptoms including altered mental status and seizures recurred 6 months after glucocorticoid discontinuation while still on mycophenolate mofetil $600 \mathrm{mg} / \mathrm{m}^{2} /$ dose twice daily. Over the next 4 years, subsequent treatments (in addition to oral steroids) included infliximab $(5 \mathrm{mg} / \mathrm{kg} /$ dose at 0,2 , and 6 weeks and every 4 weeks thereafter for 9 months), cyclophosphamide ( $10 \mathrm{mg} / \mathrm{kg} /$ dose every 2 weeks for 3 months), rituximab (3 cycles of $1000 \mathrm{mg} \times 2$ doses), azathioprine (100 mg twice daily), and IVIg (0.5g/kg every 4 weeks) with periods of improvement, followed by breakthrough clinical and MRI disease activity. Based on our experience with patients 1 and 2, FHL genetic testing 7 years after symptom onset identified biallelic pathogenic mutations in UNC13D. Patient 3 met no systemic HLH criteria, although she was too lymphopenic from previous therapy to assess NK cell function, and CSF neopterin was normal. During her course, she had recurrent sinusitis, mildly low IgG and IgA, and elevated gamma delta $\mathrm{T}$ cells (up to 19\%) while on immunosuppression; these findings were attributed to medication toxicity but may have been related to her UNC13D mutations. She received systemic dexamethasone therapy before undergoing unrelated donor HCT at age 14 years.

Patient 4, the asymptomatic sister of patient 3 , was found at age 12 years to have the same biallelic UNC13D mutations during evaluation as a potential bone marrow donor for her sister. Brain MRI demonstrated multifocal white matter lesions, one of which was contrast enhancing (figure 1). Two of the lesions increased in size over 6 weeks. Neurologic examination was normal. CSF demonstrated pleocytosis (WBC count $7 / \mu \mathrm{L}$, 92\% lymphocytes) and oligoclonal bands, but normal CSF neopterin. Laboratory evaluation demonstrated absent NK cell function and decreased CD107a expression. Similar to her sister, she was hypogammaglobulinemic (IgG 482). She met no other systemic HLH criteria. She received oral dexamethasone therapy before undergoing unrelated donor HCT.

\section{Methods}

\section{Patients and medical record review}

This study was approved by the Boston Children's Hospital and National Human Genome Research Institute Institutional Review Boards. Clinical information was obtained from the medical record.

\section{HLH diagnostic testing and pre-HCT therapy}

PRF1 and UNC13D gene sequencing was performed at the NIH or Cincinnati Children's Hospital. NK cell functional testing, perforin staining, and CD107a mobilization were performed at Cincinnati Children's Hospital. Intrathecal methotrexate and hydrocortisone and systemic dexamethasone were dosed as previously described, ${ }^{3}$ with dexamethasone weaned after HCT. 


\section{HCT procedure}

Reduced-intensity bone marrow conditioning with alemtuzumab, fludarabine, and melphalan ${ }^{7}$ was dosed as previously described. Hematopoietic stem cells were harvested from the donor bone marrow. Graft-versus-host disease (GVHD) prophylaxis included cyclosporine and methylprednisolone. Whole blood and T-cell donor chimerism studies were performed by the American Red Cross using the short tandem repeats-PCR method. Further details of the transplantation process and transplant outcomes are published separately. ${ }^{14}$

\section{Data availability}

Patient data were obtained from their electronic medical records for this study. All abstracted data are included within the manuscript, table, and figures. If additional details are needed, they can be requested from the corresponding author.

\section{Results}

\section{Hematopoietic stem cell transplantation and CNS-FHL disease response}

Following HCT, patients 1,3 , and 4 demonstrated normalization of NK cell activity and resolved MRI contrast enhancement, did not develop new brain lesions (figures 1-4) or further neurologic deficits, and had immunosuppressive glucocorticoids discontinued by 3 months post-HCT. Patient 1 had improved cranial nerve function, strength, coordination, and tremor, but continued to have significant physical deficits requiring a wheelchair or 1:1 assistance for ambulation and cognitive deficits with a full-scale IQ of 70 . Patient 2 had immunosuppressive glucocorticoids discontinued by 2 months post-HCT. Her dystonia, mental status, and strength improved at 1 year following HCT, but remains wheelchair dependent. Patient 3 had improved diplopia, gait, strength, and seizures, with resolution on levetiracetam. Patient 4 remained neurologically asymptomatic post-HCT. None of the 4 patients experienced graft failure or acute or chronic GVHD. Length of follow-up for all 4 patients ranged from 2 to 3 years posttransplant.

\section{Disease recurrence and second HCT}

Thirteen months following HCT, patient 2 experienced seizures, headache, and worsening dystonia. Biopsy of a new frontal lobe white matter enhancing lesion (figure 1) showed a dense, destructive perivascular and parenchymal lymphohistiocytic infiltrate (figure 1). Pathologic evaluation excluded posttransplant lymphoproliferative disorder, and extensive infectious testing was negative. She was diagnosed with relapsed CNS-FHL. Clinical and laboratory findings at relapse are described in the table. She met no systemic HLH criteria except decreased NK cell function. Her NK cell function was decreased despite donor chimerism greater than $46 \%$ in whole blood, $\mathrm{T}$ cells, and NK cells, which is typically considered adequate. Her sibling donor possessed a monoallelic PRF1 mutation. Upon relapse, NK cell testing in the donor revealed absent function, although decreased NK cell function has previously been noted in patients with heterozygous PRF1 mutations and the significance is uncertain. ${ }^{22}$ Patient 2 repeated remission induction with systemic dexamethasone and had a stable MRI (not shown) without new enhancement before undergoing second HCT from an unrelated donor using an alternative reduced-intensity bone marrow conditioning regimen of fludarabine, alemtuzumab and busulfan.

Twelve months posttransplant, patient 2 had normal NK cell function and no contrast-enhancing lesions on MRI (figure 1).

\section{Discussion}

We describe 4 patients with isolated CNS-FHL, who lacked any systemic HLH manifestations or typical laboratory abnormalities (other than decreased NK cell function), but carried FHL-associated mutations in PRF1 or UNC13D. It is likely that additional genetic modifying factors exist that predispose patients to CNS-isolated disease or that specific neuroinflammatory events lead to CNS involvement without triggering systemic inflammation. We did not identify an infectious trigger in our cohort, including negative testing for Epstein-Barr virus, but we cannot exclude an undetected organism or virus. Further studies will be required to identify the inherited and environmental risk factors for CNS-isolated inflammation.

Our findings of CNS-FHL as a cause of treatment-refractory, isolated neuroinflammation are an important advance in the differential diagnosis of neuroinflammatory disorders. Some notable features may facilitate diagnosis. Patients $1-3$ had overlapping symptoms including seizures $(3 / 3)$, weakness $(3 / 3)$, ataxia $(2 / 3)$, cognitive decline $(2 / 3)$, eye movement abnormalities $(2 / 3)$, headache $(2 / 3)$, and vomiting $(2 / 3)$. Symptoms typically improved with immunotherapy but recurred both during weans and active treatment. Relapses were especially common when corticosteroids were weaned or discontinued. The treatment-refractory and steroiddependent nature of the symptoms was striking. Some shared imaging characteristics include multifocal T2/fluidattenuated inversion recovery hyperintense lesions with avid enhancement and accumulation of microhemorrhages evident on susceptibility-weighted imaging. Punctate and curvilinear lesions evolved in the 3 symptomatic patients at times in their illnesses.

In these patients, CNS-FHL mimicked several CNS inflammatory disorders including CLIPPERS, MDEM, and small vessel CNS vasculitis. These diagnoses were made by treating clinicians, and presentations met the diagnostic criteria. The clinical, radiographic, and pathologic features for patient 1 meet proposed CLIPPERS diagnostic criteria. ${ }^{23}$ In addition, patients 2 and 3 had radiographic features including homogeneous enhancing nodules and curvilinear and 
punctate lesions as seen in CLIPPERS. Patient 2 met the criteria for $\mathrm{MDEM}^{16}$ early in her course. Some patients with MDEM harbor anti-myelin oligodendrocyte glycoprotein antibodies, which were not clinically available when patient 2 presented, but should now be obtained in patients with MDEM. Patient 3 met the diagnostic criteria for small vessel CNS vasculitis including pathologic confirmation.

As above, there may be clinical and radiographic features that are suggestive of CNS HLH; however, many of these features overlap with other neuroinflammatory disorders. As seen in patients 1 and 2, CNS HLH can be a destructive process with significant morbidity. As such, and in the interest of earlier diagnosis and definitive treatment, we propose that pediatric patients with treatment-refractory or recurrent CNS inflammation of uncertain etiology, including presentations consistent with CLIPPERS, MDEM (especially if anti-myelin oligodendrocyte glycoprotein antibodies are negative), and small vessel CNS vasculitis, undergo genetic testing and NK cell functional testing for FHL. Patients with refractory or recurrent neuroinflammation often require long-term immunomodulatory therapy, which can reduce the yield of a brain biopsy and alter functional testing for FHL; therefore, obtaining functional diagnostic studies before treatment is preferred. NK cell function and FHL genetic testing may eliminate the need for brain biopsy in some patients. Furthermore, our results illustrate the importance of screening siblings of patients with CNS-FHL, as early detection and treatment can limit the development of clinical symptomatology and permanent, potentially devastating neurologic sequelae.

CSF neopterin is associated with CNS involvement of $\mathrm{HLH}$ among a broad group of neuroinflammatory disorders. ${ }^{24}$ Levels were elevated in patients 1 and 2 at diagnosis and were normal following apparent disease control. CSF neopterin may provide a useful biomarker of CNS-FHL disease activity and treatment efficacy.

In addition to the importance of diagnostic clarity and genetic counseling, the diagnosis of CNS-FHL has profound treatment implications. Compared with current primary neuroinflammatory standard-of-care therapies, HCT represents a fundamentally different treatment paradigm: correcting an underlying genetic etiology as opposed to controlling inflammatory disease with chronic immunosuppression. We found that HCT using reduced-intensity conditioning regimens was tolerated by patients with CNS-FHL without engraftment failure or evidence of acute GVHD. Three of the 4 patients achieved CNS-FHL disease control following the first HCT. One patient (patient 2) relapsed in the setting of a heterozygous PRF1 mutated donor marrow with persistently decreased NK cell function despite adequate donor chimerism, but achieved normal NK cell function and disease control after a second HCT using a different bone marrow donor. These findings underscore the potential importance of screening prospective sibling stem cell donors with genetic and functional testing.
Although all patients in this cohort achieved positive outcomes and are off chronic immunosuppressive therapy, delayed diagnoses resulted in significant disability, especially for patients 1 and 2. Longer-term follow-up is required to assess response durability given reports of CNS-isolated relapses following HCT for systemic HLH. ${ }^{25,26}$ Follow-up will also help clarify optimal post-HCT monitoring protocols, including MRI, CSF, donor chimerism, and NK cell function. These initial results support efforts to pursue early and accurate diagnosis and early treatment with HCT to reduce morbidity and mortality in CNS-FHL, a novel, curable syndrome.

\section{Acknowledgment}

The authors gratefully acknowledge Biogen for providing natalizumab through compassionate use. This work was supported in part by the Intramural Research Programs of the National Human Genome Research Institute, the National Institute of Neurologic Disorders and Stroke, the National Institute of Allergy and Infectious Diseases, and the Common Fund, Office of the Director, NIH, Bethesda, MD.

\section{Study funding}

This work was supported by Intramural Research Programs of the NHGRI, NINDS, NIAID, and the NIH Common Fund, Office of the Director, NIH, Bethesda, MD (Z1DHG200352).

\section{Disclosure}

L.A. Benson received research support from Biogen, Boston Children's Hospital Office of Faculty Development, and the NMSS and served as an expert consultant for Vaccine Injury Compensation Program. H. Li received research support from the American Society of Hematology; their spouse is employed by Novartis. L.A. Henderson received speaker honoraria for systemic juvenile idiopathic arthritis with Sobi for a talk and received research support from the NIAMS and Rheumatology Research Foundation. I.H. Solomon received publishing royalties from Elsevier and consulted for S2N Health. A. Soldatos received research support from the NINDS. J. Murphy reports no disclosures. B. Bielekova received royalties from the NIH for patents related to daclizumab; received research support from the NINDS, Biogen/ AbbVie, and Santhera Pharmaceuticals; and is an employee of the Intramural Research Program of the NIH/NIAID. A.L. Kennedy received research support from the NIH/NCI. M.J. Rivkin received research support from the NINDS. K.J. Davies reports no disclosures. A.P. Hsu is a federal government employee of the NIH. S.M. Holland reports no disclosures. W. Gahl received travel funding from the Cystinosis Research Network; served as associate editor of Molecular Genetics and Metabolism; receives licensing royalties from a patent on ManNAc; and received research support from the NIH. R.P. Sundel received payment from Medical Education Resources; received speaker honoraria from Boston IBD conference and for a talk on CRMO; served as section editor of Pediatric Rheumatology and UpToDate; received publishing 
royalties from UpToDate; consulted for American College of Rheumatology, Vasculitis Committee on Pediatric Vasculitis, and Growthpoint; is a member of the Lyme Guidelines Committee; received research support from SimulConsult and NIH; and served as an expert for Sanofi. L.E. Lehmann, M.A. Lee, S. Alexandrescu, and B.A. Degar report no disclosures. C.N. Duncan served on the advisory board of Pfizer and Bluebird Bio; received publishing royalties from UptoDate; consulted for Bluebird Bio, Magenta, and AbGenomics; did review document preparation for Peer View Institute; prepared course content for Open CME; and received research support from the St. Baldrick's Foundation. M.P. Gorman received research support from Pfizer, Novartis, Biogen, and the NMSS. Go to Neurology.org/NN for full disclosure.

\section{Publication history}

Received by Neurology: Neuroimmunology \& Neuroinflammation January 8, 2019. Accepted in final form February 15, 2019.

Appendix Author contributions

\begin{tabular}{|c|c|c|c|}
\hline Name & Location & Role & Contribution \\
\hline $\begin{array}{l}\text { Leslie A. } \\
\text { Benson, MD }\end{array}$ & $\begin{array}{l}\text { Department of } \\
\text { Neurology, Boston } \\
\text { Children's } \\
\text { Hospital, Boston, } \\
\text { MA }\end{array}$ & Author & $\begin{array}{l}\text { Designed and } \\
\text { conceptualized the } \\
\text { study, acquisition of } \\
\text { data, drafted the } \\
\text { manuscript, and } \\
\text { revised the } \\
\text { manuscript for } \\
\text { intellectual content }\end{array}$ \\
\hline $\begin{array}{l}\text { Hojun Li, MD, } \\
\text { PhD }\end{array}$ & $\begin{array}{l}\text { Dana-Farber/ } \\
\text { Boston Children's } \\
\text { Cancer and Blood } \\
\text { Disorders Center, } \\
\text { Boston, MA }\end{array}$ & Author & $\begin{array}{l}\text { Designed and } \\
\text { conceptualized the } \\
\text { study, acquisition of } \\
\text { data, drafted the } \\
\text { manuscript, and } \\
\text { revised the } \\
\text { manuscript for } \\
\text { intellectual content }\end{array}$ \\
\hline $\begin{array}{l}\text { Lauren A. } \\
\text { Henderson, } \\
\text { MD }\end{array}$ & $\begin{array}{l}\text { Department of } \\
\text { Rheumatology, } \\
\text { Boston Children's } \\
\text { Hospital, Boston, } \\
\text { MA }\end{array}$ & Author & $\begin{array}{l}\text { Acquisition of data } \\
\text { and revised the } \\
\text { manuscript for } \\
\text { intellectual content }\end{array}$ \\
\hline $\begin{array}{l}\text { Isaac H. } \\
\text { Solomon, MD, } \\
\text { PhD }\end{array}$ & $\begin{array}{l}\text { Department of } \\
\text { Pathology, Boston } \\
\text { Children's } \\
\text { Hospital, Boston, } \\
\text { MA }\end{array}$ & Author & $\begin{array}{l}\text { Acquisition of data } \\
\text { and revised the } \\
\text { manuscript for } \\
\text { intellectual content }\end{array}$ \\
\hline $\begin{array}{l}\text { Ariane } \\
\text { Soldatos, MD, } \\
\text { MPH }\end{array}$ & $\begin{array}{l}\text { Undiagnosed } \\
\text { Disease Program } \\
\text { of the National } \\
\text { Institute of } \\
\text { Neurologic } \\
\text { Disorders and } \\
\text { Stroke, Bethesda, } \\
\text { MD }\end{array}$ & Author & $\begin{array}{l}\text { Acquisition of data } \\
\text { and revised the } \\
\text { manuscript for } \\
\text { intellectual content }\end{array}$ \\
\hline $\begin{array}{l}\text { Jennifer } \\
\text { Murphy, NP }\end{array}$ & $\begin{array}{l}\text { Undiagnosed } \\
\text { Disease Program } \\
\text { of the National } \\
\text { Institute of } \\
\text { Neurologic } \\
\text { Disorders and } \\
\text { Stroke, Bethesda, } \\
\text { MD }\end{array}$ & Author & $\begin{array}{l}\text { Revised the } \\
\text { manuscript for } \\
\text { intellectual content. }\end{array}$ \\
\hline
\end{tabular}

Appendix (continued)

\begin{tabular}{|c|c|c|c|}
\hline Name & Location & Role & Contribution \\
\hline $\begin{array}{l}\text { Bibiana } \\
\text { Bielekova, MD }\end{array}$ & $\begin{array}{l}\text { Undiagnosed } \\
\text { Disease Program } \\
\text { of the National } \\
\text { Institute of } \\
\text { Neurologic } \\
\text { Disorders and } \\
\text { Stroke, Bethesda, } \\
\text { MD }\end{array}$ & Author & $\begin{array}{l}\text { Acquisition and } \\
\text { interpretation of } \\
\text { immunophenotyping } \\
\text { data, participation in } \\
\text { diagnostic workup, } \\
\text { and revised the } \\
\text { manuscript for } \\
\text { intellectual content }\end{array}$ \\
\hline $\begin{array}{l}\text { Alyssa L. } \\
\text { Kennedy, MD, } \\
\text { PhD }\end{array}$ & $\begin{array}{l}\text { Dana-Farber/ } \\
\text { Boston Children's } \\
\text { Cancer and Blood } \\
\text { Disorders Center, } \\
\text { Boston, MA }\end{array}$ & Author & $\begin{array}{l}\text { Revised the } \\
\text { manuscript for } \\
\text { intellectual content. }\end{array}$ \\
\hline $\begin{array}{l}\text { Michael J. } \\
\text { Rivkin, MD }\end{array}$ & $\begin{array}{l}\text { Department of } \\
\text { Neurology, Boston } \\
\text { Children's Hospital, } \\
\text { Boston, MA }\end{array}$ & Author & $\begin{array}{l}\text { Revised the } \\
\text { manuscript for } \\
\text { intellectual content. }\end{array}$ \\
\hline $\begin{array}{l}\text { Kimberly J. } \\
\text { Davies, MD }\end{array}$ & $\begin{array}{l}\text { Dana-Farber/ } \\
\text { Boston Children's } \\
\text { Cancer and Blood } \\
\text { Disorders Center, } \\
\text { Boston, MA }\end{array}$ & Author & $\begin{array}{l}\text { Revised the } \\
\text { manuscript for } \\
\text { intellectual content. }\end{array}$ \\
\hline Amy P. Hsu, BA & $\begin{array}{l}\text { Laboratory of } \\
\text { Clinical } \\
\text { Immunology and } \\
\text { Microbiology, } \\
\text { National Institute } \\
\text { of Allergy and } \\
\text { Infectious } \\
\text { Diseases, } \\
\text { Bethesda, MD }\end{array}$ & Author & $\begin{array}{l}\text { Diagnosed and } \\
\text { performed genetic } \\
\text { testing for patient and } \\
\text { revised the } \\
\text { manuscript for } \\
\text { intellectual content }\end{array}$ \\
\hline $\begin{array}{l}\text { Steven M. } \\
\text { Holland, MD }\end{array}$ & $\begin{array}{l}\text { Laboratory of } \\
\text { Clinical } \\
\text { Immunology and } \\
\text { Microbiology, } \\
\text { National Institute of } \\
\text { Allergy and } \\
\text { Infectious Diseases, } \\
\text { Bethesda, MD }\end{array}$ & Author & $\begin{array}{l}\text { Care for Patient } 1 \text { and } \\
\text { revised the } \\
\text { manuscript for } \\
\text { intellectual content. }\end{array}$ \\
\hline $\begin{array}{l}\text { William A. } \\
\text { Gahl, MD, PhD }\end{array}$ & $\begin{array}{l}\text { National Human } \\
\text { Genome Research } \\
\text { Institute, } \\
\text { Bethesda, MD }\end{array}$ & Author & $\begin{array}{l}\text { Revised the } \\
\text { manuscript for } \\
\text { intellectual content. }\end{array}$ \\
\hline $\begin{array}{l}\text { Robert P. } \\
\text { Sundel, MD }\end{array}$ & $\begin{array}{l}\text { Department of } \\
\text { Rheumatology, } \\
\text { Boston Children's } \\
\text { Hospital, Boston, } \\
\text { MA }\end{array}$ & Author & $\begin{array}{l}\text { Revised the } \\
\text { manuscript for } \\
\text { intellectual content. }\end{array}$ \\
\hline $\begin{array}{l}\text { Leslie E. } \\
\text { Lehmann, MD }\end{array}$ & $\begin{array}{l}\text { Dana-Farber/ } \\
\text { Boston Children's } \\
\text { Cancer and Blood } \\
\text { Disorders Center, } \\
\text { Boston, MA }\end{array}$ & Author & $\begin{array}{l}\text { Revised the } \\
\text { manuscript for } \\
\text { intellectual content. }\end{array}$ \\
\hline $\begin{array}{l}\text { Michelle A. } \\
\text { Lee, MD, PhD }\end{array}$ & $\begin{array}{l}\text { Division of } \\
\text { Hematology, } \\
\text { Oncology, and } \\
\text { Marrow \& Blood Cell } \\
\text { Transplantation, } \\
\text { Children's Hospital } \\
\text { at Montefiore, } \\
\text { Bronx, NY }\end{array}$ & Author & $\begin{array}{l}\text { Revised the } \\
\text { manuscript for } \\
\text { intellectual content. }\end{array}$ \\
\hline $\begin{array}{l}\text { Sanda } \\
\text { Alexandrescu, } \\
\text { MD }\end{array}$ & $\begin{array}{l}\text { Department of } \\
\text { Pathology, Boston } \\
\text { Children's } \\
\text { Hospital, Boston, } \\
\text { MA }\end{array}$ & Author & $\begin{array}{l}\text { Revised the } \\
\text { manuscript for } \\
\text { intellectual content. }\end{array}$ \\
\hline
\end{tabular}


Appendix (continued)

\begin{tabular}{llll}
\hline Name & Location & Role & Contribution \\
\hline $\begin{array}{l}\text { Barbara A. } \\
\text { Degar, MD }\end{array}$ & $\begin{array}{l}\text { Dana-Farber/ } \\
\text { Boston Children's } \\
\text { Cancer and Blood } \\
\text { Disorders Center, } \\
\text { Boston, MA }\end{array}$ & Author & $\begin{array}{l}\text { Revised the } \\
\text { manuscript for } \\
\text { intellectual content. }\end{array}$ \\
\hline $\begin{array}{llll}\text { Christine N. } \\
\text { Duncan, MD }\end{array}$ & $\begin{array}{l}\text { Dana-Farber/ } \\
\text { Boston Children's } \\
\text { Cancer and Blood } \\
\text { Disorders Center, } \\
\text { Boston, MA }\end{array}$ & Author & $\begin{array}{l}\text { Designed and } \\
\text { conceptualized the } \\
\text { study and revised the } \\
\text { manuscript for } \\
\text { intellectual content }\end{array}$ \\
\hline $\begin{array}{l}\text { Mark P. } \\
\text { Gorman, MD }\end{array}$ & $\begin{array}{lll}\text { Department of } \\
\text { Neurology, Boston } \\
\text { Children's } \\
\text { Hospital, Boston, } \\
\text { MA }\end{array}$ & Author & $\begin{array}{l}\text { Designed and } \\
\text { conceptualized the } \\
\text { study and revised the } \\
\text { manuscript for } \\
\text { intellectual content }\end{array}$ \\
& &
\end{tabular}

\section{References}

1. Deiva K, Mahlaoui N, Beaudonnet F, et al. CNS involvement at the onset of primary hemophagocytic lymphohistiocytosis. Neurology 2012;78:1150-1156.

2. Horne A, Trottestam $\mathrm{H}$, Aricò $\mathrm{M}$, et al. Frequency and spectrum of central nervous system involvement in 193 children with haemophagocytic lymphohistiocytosis. Br J Haematol 2008;140:327-335.

3. Henter JI, Horne A, Aricó M, et al. HLH-2004: diagnostic and therapeutic guidelines for hemophagocytic lymphohistiocytosis. Pediatr Blood Cancer 2007;48:124-131.

4. Degar B. Familial hemophagocytic lymphohistiocytosis. Hematol Oncol Clin North Am 2015;29:903-913.

5. Zhang K, Filipovich AH, Johnson J, Marsh RA, Villanueva J. Hemophagocytic lymphohistiocytosis, familial. In: Pagon RA, Adam MP, Ardinger HH, et al, editors. GeneReviews ${ }^{\oplus}$. Seattle: University of Washington; 1993.

6. Fischer A, Cerf-Bensussan N, Blanche $S$, et al. Allogeneic bone marrow transplantation for erythrophagocytic lymphohistiocytosis. J Pediatr 1986;108:267-270.

7. Marsh RA, Kim MO, Liu C, et al. An intermediate alemtuzumab schedule reduces the incidence of mixed chimerism following reduced-intensity conditioning hematopoietic cell transplantation for hemophagocytic lymphohistiocytosis. Biol Blood Marrow Transpl 2013;19:1625-1631.

8. Shinoda J, Murase S, Takenaka K, Sakai N. Isolated central nervous system hemophagocytic lymphohistiocytosis: case report. Neurosurgery 2005;56:187.

9. Moshous D, Feyen O, Lankisch P, et al. Primary necrotizing lymphocytic central nervous system vasculitis due to perforin deficiency in a four-year-old girl. Arthritis Rheum 2007;56:995-999.
10. Tesi B, Chiang SC, El-Ghoneimy D, et al. Spectrum of atypical clinical presentations in patients with Biallelic PRF1 Missense mutations. Pediatr Blood Cancer 2015;62: 2094-2100.

11. Khazal S, Polishchuk V, Soffer G, Prinzing S, Gill J, Mahadeo KM. Allogeneic hematopoietic stem cell transplantation is associated with cure and durable remission of late-onset primary isolated central nervous system hemophagocytic lymphohistiocytosis. Pediatr Transpl 2017;22:e13101.

12. Algahtani H, Absi A, Bassuni W, Shirah B. Adult-onset hemophagocytic lymphohistiocytosis type 2 presenting as a demyelinating disease. Mult Scler Relat Disord 2018; 25:77-82.

13. Solomon IH, Li H, Benson LA, et al. Histopathologic correlates of familial hemophagocytic lymphohistiocytosis isolated to the central nervous system. J Neuropathol Exp Neurol 2018;77:1079-1084.

14. Li H, Benson LA, Henderson LA, et al. Central nervous system-restricted familial hemophagocytic lymphohistiocytosis responds to hematopoietic cell transplantation. Blood Adv 2019;3:503-507.

15. Bigi S, Fischer U, Wehrli E, et al. Acute ischemic stroke in children versus young adults. Ann Neurol 2011;70:245-254.

16. Krupp LB, Tardieu M, Amato MP, et al. International Pediatric Multiple Sclerosis Study Group criteria for pediatric multiple sclerosis and immune-mediated central nervous system demyelinating disorders: revisions to the 2007 definitions. Mult Scler 2013;19:1261-1267.

17. Pittock SJ, Debruyne J, Krecke KN, et al. Chronic lymphocytic inflammation with pontine perivascular enhancement responsive to steroids (CLIPPERS). Brain 2010; 133:2626-2634

18. Hutchinson C, Elbers J, Halliday W, et al. Treatment of small vessel primary CNS vasculitis in children: an open-label cohort study. Lancet Neurol 2010;9:1078-1084.

19. Gahl WA, Markello TC, Toro C, et al. The National Institutes of Health Undiagnosed Diseases Program: insights into rare diseases. Genet Med 2012;14:51-59.

20. Gahl WA, Mulvihill JJ, Toro C, et al. The NIH Undiagnosed Diseases Program and Network: applications to modern medicine. Mol Genet Metab 2016;117:393-400.

21. Han S, Lin YC, Wu T, et al. Comprehensive immunophenotyping of cerebrospinal fluid cells in patients with neuroimmunological diseases. J Immunol 2014;192: 2551-2563.

22. Rubin TS, Zhang K, Gifford C, et al. Perforin and CD107a testing is superior to NK cell function testing for screening patients for genetic HLH. Blood 2017;129: 2993-2999.

23. Tobin WO, Guo Y, Krecke KN, et al. Diagnostic criteria for chronic lymphocytic inflammation with pontine perivascular enhancement responsive to steroids (CLIPPERS). Brain 2017;140:2415-2425.

24. Howells DW, Strobel S, Smith I, Levinsky RJ, Hyland K. Central nervous system involvement in the erythrophagocytic disorders of infancy: the role of cerebrospinal fluid neopterins in their differential diagnosis and clinical management. Pediatr Res 1990;28:116-119.

25. Bock AM, LeVeque M, Camitta B, Talano JA. Successful treatment of recurrent CNS disease post-bone marrow transplant in children with familial hemophagocytic lymphohistiocytosis. Pediatr Blood Cancer 2016;63:2154-2158.

26. Lounder DT, Khandelwal P, Chandra S, et al. Incidence and outcomes of central nervous system hemophagocytic lymphohistiocytosis relapse after reduced-intensity conditioning hematopoietic stem cell transplantation. Biol Blood Marrow Transpl 2017;23:857-860. 


\section{Neurology \\ Neuroimmunology \& Neuroinflammation}

Pediatric CNS-isolated hemophagocytic lymphohistiocytosis

Leslie A. Benson, Hojun Li, Lauren A. Henderson, et al.

Neurol Neuroimmunol Neuroinflamm 2019;6;

DOI 10.1212/NXI.0000000000000560

This information is current as of April 8, 2019

Neurol Neuroimmunol Neuroinflamm is an official journal of the American Academy of Neurology.

Published since April 2014, it is an open-access, online-only, continuous publication journal. Copyright

Copyright $\odot 2019$ The Author(s). Published by Wolters Kluwer Health, Inc. on behalf of the American

Academy of Neurology.. All rights reserved. Online ISSN: 2332-7812.

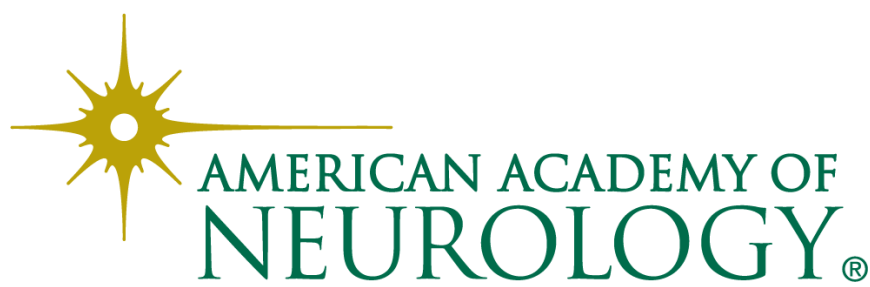




\section{Updated Information \& Services}

References

Citations

Subspecialty Collections

Permissions \& Licensing

Reprints including high resolution figures, can be found at: http://nn.neurology.org/content/6/3/e560.full.html

This article cites 25 articles, 3 of which you can access for free at: http://nn.neurology.org/content/6/3/e560.full.html\#\#ref-list-1

This article has been cited by 5 HighWire-hosted articles: http://nn.neurology.org/content/6/3/e560.full.html\#\#otherarticles

This article, along with others on similar topics, appears in the following collection(s):

\section{All Genetics}

http://nn.neurology.org//cgi/collection/all_genetics All Pediatric

http://nn.neurology.org//cgi/collection/all_pediatric

Autoimmune diseases

http://nn.neurology.org//cgi/collection/autoimmune_diseases

\section{Encephalitis}

http://nn.neurology.org//cgi/collection/encephalitis

Hematologic

http://nn.neurology.org//cgi/collection/hematologic

Information about reproducing this article in parts (figures,tables) or in its entirety can be found online at:

http://nn.neurology.org/misc/about.xhtml\#permissions

Information about ordering reprints can be found online:

http://nn.neurology.org/misc/addir.xhtml\#reprintsus

Neurol Neuroimmunol Neuroinflamm is an official journal of the American Academy of Neurology.

Published since April 2014, it is an open-access, online-only, continuous publication journal. Copyright

Copyright $\odot 2019$ The Author(s). Published by Wolters Kluwer Health, Inc. on behalf of the American

Academy of Neurology.. All rights reserved. Online ISSN: 2332-7812.

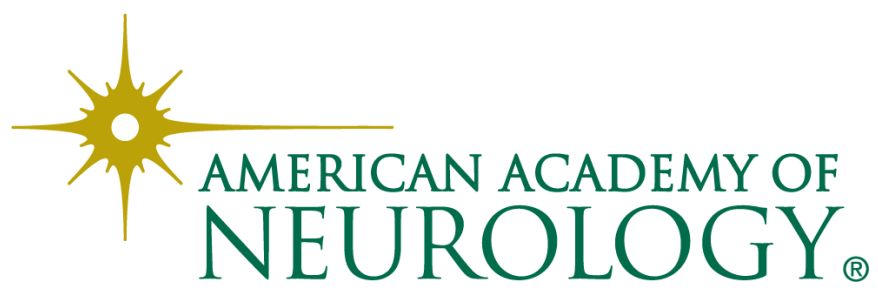

